\title{
Principal maize viruses in Mediterranean countries
}

\author{
D Ivanović ${ }^{1 *}, \mathrm{R}$ Osler $^{2}, \mathrm{~N}$ Katis ${ }^{3}, \mathrm{M}$ Ivanović ${ }^{4}$, D Ignjatović ${ }^{1}$ \\ 1 Maize Research Institute, Zemun Polje, Belgrade-Zemun, Serbia; \\ 2 Department of Biology Applied to Plant Protection, University of Udine, Italy; \\ ${ }^{3}$ Aristotle University, Faculty of Agriculture, 54006 Thessaloniki, Greece; \\ ${ }^{4}$ Faculty of Agriculture, University of Belgrade, Serbia
}

(Received 20 May 1995; accepted 4 July 1995)

\begin{abstract}
Summary - Maize plants with virus-like symptoms were sampled in fields in Greece, Yugoslavia and Italy in 1994. Disease incidence (\%) and disease severity (1-6) were assessed. Leaf samples were tested by enzyme-linked immunosorbent assay (ELISA) and electroblot immunoassay (EBIA). Antisera against maize dwarf mosaic virus (MDMV), sugarcane mosaic virus (SCMV) and barley yellow dwarf viruses (BYDVs) (PAV-and RPV-like) were used in these tests. A higher disease incidence occurred in Italy and Greece than in Yugoslavia. MDMV was proved by both ELISA and EBIA in all maize genotypes in Greece, Yugoslavia and Italy. None of the samples reacted with SCMV antibodies. A total of 13.7 and $11 \%$ of individual Greek samples were positive for PAV- and RPV- respectively, while, 17.5 and $5 \%$ of Yugoslav samples were positive for PAV- and RPV- respectively. Phragmites sp, a perennial maize weed, was also positive for PAV- and RPV- by ELISA.
\end{abstract}

\section{BYDV / Zea mays $\mathrm{L}=$ maize $/ \mathrm{MDMV} /$ Mediterranean region}

Résumé - Principaux virus du maïs dans les pays méditerranéens. En 1994, des échantillons de feuilles de maïs présentant des symptômes de type viral ont été prélevés au champ, en Grèce (Gr), en Yougoslavie (Yu), et en Italie (It). L'incidence de la maladie a été évaluée en \% et sa gravité notée de 1 à 6 . Les échantillons de feuilles ont été testés par ELISA et par immuno-essai par électro-transfert (EBIA). Les antisera, anti-MDMV, anti-SCMV, et anti-BYDV (PAV-et RPV-like) furent utilisés dans ces tests. La maladie a eu une incidence assez élevée en Italie et en Grèce, mais moindre en Yougoslavie. La présence de MDMV est confirmée en ELISA comme en EBIA, chez tous les génotypes de maïs, dans les 3 pays. Aucun des échantillons n'a réagi avec les anticorps du SCMV. Onze et 13\% des échantillons originaires de Grèce et 17,5 et $5 \%$ des isolats de Yougoslavie se sont révélés positifs respectivement en PAV-et RPV-. Le Phragmites sp, une mauvaise herbe du maiss, a réagi aussi positivement vis-à-vis du PAV et du RPV par ELISA.

$B Y D V /$ Zea mays $L=$ maïs $/ M D M V /$ région méditerranéenne

\footnotetext{
${ }^{*}$ Correspondence and reprints
} 


\section{INTRODUCTION}

Until the end of the 1980s maize dwarf mosaic virus (MDMV) was the only economically important viral pathogen on maize in Greece, Italy and Yugoslavia (Panayotou, 1980; Conti, 1982; Tošić et al, 1990). Sudden and rapid virus spread in maize fields occurred in 1989, 1990 and 1991 in the southern part of Europe, leading to a more extensive study of the diseases caused. This study showed, both in transmission trials by aphid vectors and by enzyme-linked immunosorbent assay (ELISA), that barley yellow dwarf virus (BYDV) was present on maize in Yugoslavia (Ivanović et al, 1992). Moreover, a few authors revealed for the first time, that a mosaic type of symptoms on maize in this area was caused by the sugarcane mosaic virus SCMV (Ivanović et al, 1993; Krstić and Tošić, 1995). Belli et al (1980) and Osler et al (1985) described BYDV on maize, while Guinchedi and Credi (1990) reported the presence of SCMV on maize in Italy in 1989. Although they identified MDMV in 1990, they did not detect SCMV. Taking into account such information, we tried to estimate the incidence and frequency of viruses infecting maize in this part of Mediterranean region.

\section{MATERIALS AND METHODS}

Leaf samples of maize plants with virus-like symptoms were collected in July and August, 1994. A total of 44, 40 and 6 leaf samples were collected in Greece, Yugoslavia and Italy, respectively. All Greek (Gr) samples were collected from the prefecture of Thessaloniki. Yugoslav (Yu) samples were collected in Vojvodina, the major maize production area, while Italian (It) samples were derived from the north-east part of the country, the province of Friuly. Investigations were carried out on commercial maize crops (Gr, It and $\mathrm{Yu}$ samples) and on inbred lines ( $\mathrm{Yu}$ sample). The disease incidence (\%) was assessed by screening 300 plants $(3 \times 100)$. Disease severity was scored on a scale ranging from 1 (healthy plants) to 6 (systemic infection with stunting) and was calculated for the infected plants only. The screening of maize plants in Greece was the exception, as symptoms were rather mild and the disease severity was denoted as $M$. Leaf samples were stored at $-18^{\circ} \mathrm{C}$ until serological assay were applied. Standard methods were used for a double-antibody sandwich ELISA. Antisera against MDMV and SCMV were prepared at the University of Illinois, USA (Ivanović et al, 1995). BYDV serotypes were determined on the basis of 2 antisera, PAV and RPV produced by Sanofi - Phyto-diagnostics (France). Positive controls for the BYDV serotypes were air-dried infected oat tissue, while infected maize tissue was positive controls for MDMV and SCMV. Negative controls were extracts from healthy plants. Absorbance $\left(\mathrm{A}_{405}\right)$ was measured with a Multiskan colorimeter (type 314). Leaf samples were considered positive when the mean $A_{405}$ value of the replicate samples was twice as large as the mean absorbance of negative controls in the same plate. Virus-specific antibodies for both MDMV and SCMV were used in electroblot immunoassay (EB|A) according to Ivanović et al (1995).

\section{RESULTS}

Mosaic and dwarfing were dominant symptoms of infected plants. The first MDMV symptoms in the observed region, appeared in late May and early June 1994. Based on the field observations a higher incidence of viruses on maize was detected in Italy and Greece than in Yugoslavia. All maize genotypes, tested by ELISA, were positive for MDMV (table I). Only 9\% of individual Gr maize samples were negative for MDMV. Italian samples were only positive for MDMV. None of the tested samples was positive for SCMV in the ELISA test.

Serological analyses of maize samples with virus-specific antibodies in EBIA confirmed positive reaction for MDMV (fig 1 ). No samples reacted with virus-specific or unpurified SCMV antibodies.

Infection of maize by BYDV was associated with reddening of leaves starting from the tip and the margin. Concerning the individual Gr samples, 13.7 and $11 \%$ were positive for PAV- and RPV-like BYDV isolates, while 17.5 and $5 \%$ of $Y u$ samples were positive for PAV- and RPV-like isolates, respectively.

Phragmites sp, a perennial maize weed originated from Greece, was positive for PAV- and RPV-like BYDV isolates in ELISA. There were no visible symptoms on this species in the field. However, this weed species was heavily infested with aphids and may have an important role in epidemiology of BYDV disease in the area.

\section{DISCUSSION}

Analyses of a limited number of maize samples from Greece, Yugoslavia and Italy revealed that MDMV was a dominant virus on maize in this region. These results are in accordance with our previous data gained for maize plants derived from the Lombardy and Vojvodina provinces, the 
Table I. Incidence of MDMV and BYDV, symptoms and ELISA results of samples collected in maize fields during the 1994 survey in Greece, Yugoslavia and Italy.

\begin{tabular}{|c|c|c|c|c|c|c|c|}
\hline \multirow[t]{3}{*}{ Sample } & \multirow[t]{3}{*}{ Genotype } & \multirow{3}{*}{$\begin{array}{l}\text { Disease incidence }{ }^{a} \\
\text { /disease severity }^{\mathrm{b}}\end{array}$} & \multirow[t]{3}{*}{ Type of symptom ${ }^{c}$} & \multicolumn{4}{|c|}{ ELISA results d } \\
\hline & & & & \multirow[t]{2}{*}{$M D M V$} & \multirow[t]{2}{*}{$S C M V$} & \multicolumn{2}{|c|}{$B Y D V$} \\
\hline & & & & & & PAV & $R P V$ \\
\hline $1-9 \mathrm{Gr}$ & Nickerson 7003 & $60 / M$ & Mo; St; Red & + & - & - & + \\
\hline $10-14 \mathrm{Gr}$ & Agribest & $40 / M$ & $\mathrm{Mo} ; \mathrm{St}$ & + & - & - & - \\
\hline $15-16 \mathrm{Gr}$ & ZP 704 & $35 / M$ & Mo; St & + & - & - & - \\
\hline $17-28 \mathrm{Gr}$ & Unknown & $40 / M$ & Mo; St; Red & + & - & - & + \\
\hline $29 \mathrm{Gr}$ & Phragmites sp & - & - & - & - & + & + \\
\hline $30-33 \mathrm{Gr}$ & Unknown & $50 / M$ & Mo; St; Red & + & - & + & + \\
\hline $34-44 \mathrm{Gr}$ & Unknown & $20 / M$ & Mo; St; Red & + & - & + & - \\
\hline 1-9 Yu & Mo 17 & $52 / 3.5$ & Mo; St & + & - & - & - \\
\hline $10-12 \mathrm{Yu}$ & B 73M & $14 / 2.5$ & Mo; Red & + & - & + & - \\
\hline $13-14 \mathrm{Yu}$ & B 73 & $30 / 2.8$ & Mo; St; Red & + & - & + & + \\
\hline $15-18 \mathrm{Yu}$ & B 84 & $11 / 3.0$ & Mo & + & - & - & - \\
\hline $19-20 \mathrm{Yu}$ & Va 35 & $19 / 2.5$ & Mo & + & - & - & - \\
\hline $21-23 \mathrm{YU}$ & B 432 & $40 / 3.2$ & Mo; Red & + & - & + & - \\
\hline $24-29 \mathrm{Yu}$ & Unknown inbreds & $7 / 2.7$ & Mo; Ch; Red & + & - & + & + \\
\hline $30-40 \mathrm{Yu}$ & Unknown hybrids & $27 / 3.2$ & Mo; St; Red & + & - & + & - \\
\hline $1-3$ It & Unknown hybrid & $85 / 3.0$ & Mo & + & - & - & - \\
\hline $4-5 \mathrm{It}$ & Unknown hybrid & $54 / 4.0$ & Mo; St & + & - & - & - \\
\hline $6 \mathrm{It}$ & Unknown hybrid & $15 / 6.0$ & Mo; St & + & - & - & - \\
\hline
\end{tabular}

a Disease incidence $(\%)$ was assessed according to screening of 300 plants $(3 \times 100)$. b Disease severity was scored on a scale ranging from 1 (healthy plants) to 6 (systemic infection with stunting) and was calculated for the infected plants only; $M=$ mild symptoms. c Mo = mosaic; $\mathrm{St}=$ stunting; Red $=$ reddening; $\mathrm{Ch}=$ chlorosis; $-=$ no symptoms. ${ }^{d}$ Results according to threshold $(+)$ positive and $(-)$ negative; individual samples were tested in 4 replications and were repeated. twice.

main maize-growing areas in Italy and Yugoslavia (Ivanovic et al, 1995). It was also proved that SCMV was not present or frequent, in this area. SCMV was actually found in nursery at Zemun Polje in 1992, where a wide range of genetic variability concentrated in a small area, offsetting a spectrum of symptoms (Ivanović et al, 1993). Relatively small number of tested samples and low frequency of SCMV were probably the reason for failure in detecting the virus.

MDMV was known as a maize pathogen in Greece (Panayotou, 1980). The trend to expand maize growthing in this country had led to a more extensive research on these diseases, emphasising BYDV, as the first to be discovered on maize by this study.

The finding that the PAV-like strain of BYDV was dominant in Greece and Yugoslavia is in agreement with previously reported data from Italy (Osler et al, 1985). The PAV-like stain is also dominant in some other Mediterranean countries, eg, Syria and Tunisia (Makkouk et al, 1987 ) and Spain (Moriones and Garcia-Arenal, 1991).

In epiphytotic years of maize virus occurrence, 1989 and 1991, BYDV symptoms on maize inbred lines became visible by the end of May and early June. BYDV symptoms were mostly associated with MDMV symptoms, causing severe plant stunting and yield reduction. In our previous experiments, performed in field conditions with 81 maize inbred lines at Zemun Polje, it was found that more than 90 and $24 \%$ of them were infected by MDMV and BYDV, respectively (Ivanović et al, 1992).

Due to the high susceptibility of some maize inbred lines to BYDV and MDMV, they were replaced in seed production by new improved versions expressing less severe symptoms. We believe that a widely used BSSS population in maize breeding programs, after 1970s, had influence on the appearance of BYDV on maize in 

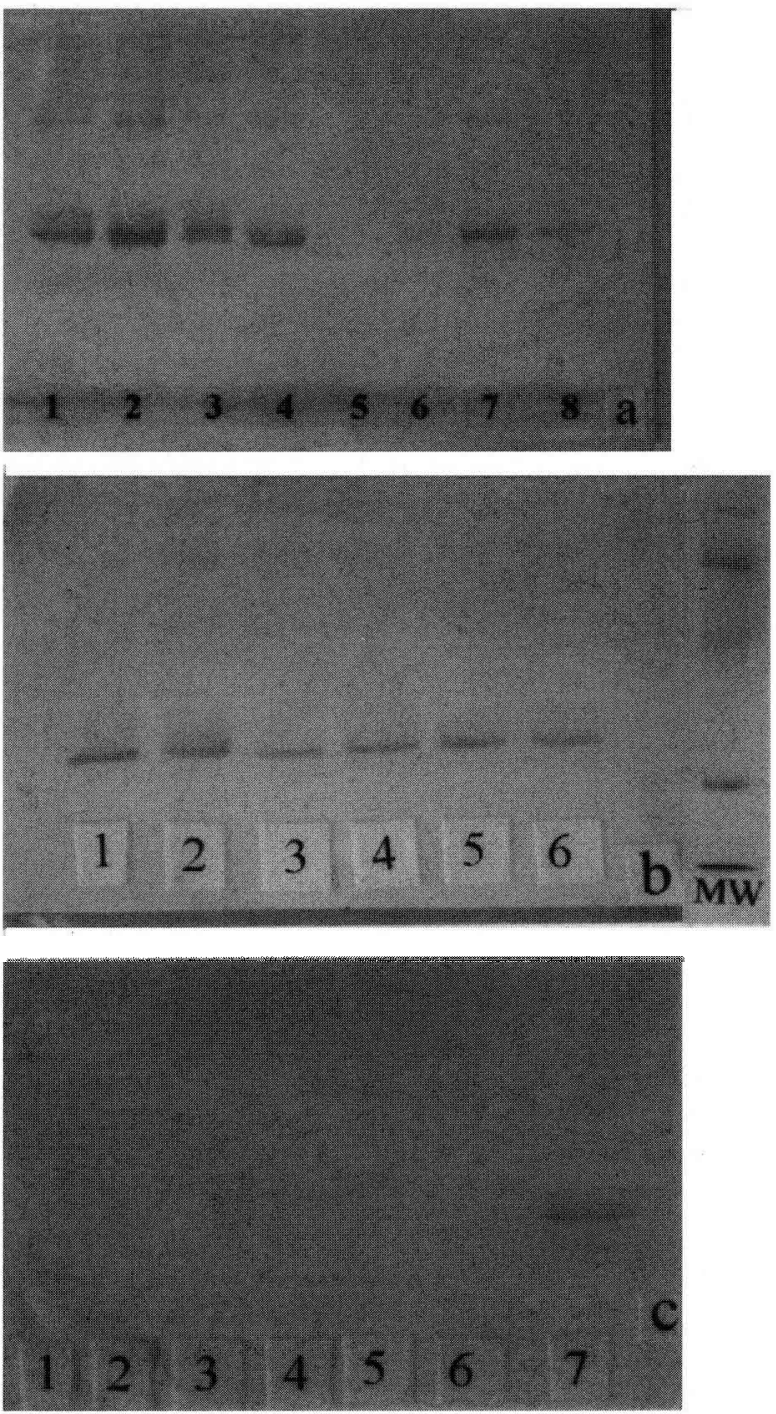

Fig 1. Electroblot immunoassay $(E B \mid A)$ of maize leaf samples probes with virus-specific antibodies. a) Lanes 1-4 and 6-8 represent $Y u$ samples probed with MDMV antibodies; lane 5: Yu sample not infected by MDMV; b) lanes 1-2, 3-4 and 5-6 represent $\mathrm{Gr}, \mathrm{Yu}$ and It samples, respectively, probed with MDMV antibodies; c) lanes 1-6 represent the same samples as in the block $\mathbf{b}$, probed with SCMV antibodies; lane 7 represents SCMV antigen. $\mathrm{MW}=$ molecular weight markers: phosphorylase b (97.4 kDa); bovine serum albumin ( $67 \mathrm{kDa})$; egg albumin (45 kDa); bovine pancreas chymotrypsinogen ( 25 $\mathrm{kDa})$; equine myoglobin (17.8 kDa).

this region. Although BYDV is present on maize in Yugoslavia, it does not appear to be a problem in commercial maize production. It may be destructive only in early epiphytotic appearance in seed production.

It was interesting to note that Phragmites $\mathrm{sp}$ was ELISA positive for PAV and RPV like BYDV isolates. Jorda et al (1987) found by ELISA and transmission techniques that Phragmites sp was a host of BYDV in Spain. This perennial species may have important role in epidemiology of
BYDV disease since it is very common weed in some maize fields in the Mediterranean region.

On the basis of this and previous studies, it was established that MDMV and PAV-like strain of BYDV are principal maize viruses in Greece, Yugoslavia and Italy, and a future control should include breeding of resistant maize genotypes to both viruses.

\section{REFERENCES}

Belli G, Cinquanta S, Soncini C (1980) Infezioni miste da MSMV (maize dwarf mosaic virus) e BYDV (barley yellow dwarf virus) in piante di mais in Lombardia. Riv Pat Veg S IV 16, 83-86

Conti M (1982) Maize viruses and virus diseases in Italy and other Mediterranean countries. Proc Intern Maize Virus Disease Colloq and Workshop, Wooster, OH, USA, 103-112

Giunchedi J, Credi R (1990) Serological detection of potyviruses infecting inbred maize lines and sorghum in Northern Italy. II. Nat Maize Conf Research, Economy, Environment, Grado (GO), Italy, Sept 19-21, 535-541

Ivanović D, Levic' J, Ivanović M, Penèić V (1992) Barley yellow dwarf virus in maize in Yugoslavia. Maydica 37, 287-292

Ivanović D, Penèić V, Lević J (1993) Obolenje kukuruza prouzrokovano virusom mozaika sećerne trske (SCMV). Savrem poljopr 41, 69-73

Ivanović D, Osler R, Ignjatović D, Ivanović M (1995) Polyclonal antibodies in detection of Potyviruses as maize pathogens. Maydica 40 (in press)

Jorda C, Osca JM, Alfaro A (1987) Comparative study of the Spanish strains of BYDV. 7th Congr Mediterr Phytopathol Union Granada, Spain, 106-107

Krstić B, Tošić M (1995) Sugarcane mosaic virus: an important pathogen on maize in Yugoslavia. $J$ Plant Dis Protec 102, 34-39

Makkouk KM, Azzam OI, Skaf JS, El-Yamani M, Cherif C, Zouba A (1987) Situation review of barley yellow dwarf virus in West Asia and North Africa. In: World Perspectives on Barley Yellow Dwarf (PA Burnett, ed), CIMMYT, Mexico, 61-65

Moriones E, Garcia-Arenal F (1991) Occurrence of barley yellow dwarf viruses in small-grain cereals. Plant Dis 75, 930-934

Osler R, Loi N, Lorenzoni C, Snidaro M, Refatti E (1985) Barley yellow dwarf virus infections in maize (Zea mays L), inbreds and hybrids in northern Italy. Maydica 30, 285-299

Panayotou PC (1980) Maize dwarf mosaic virus in Greece. Plant Dis 64, 803-804

Tošić M, Krstić B, Janković D (1990) Epidemijska pojava mozaiène krljavosti kukuruza u Jugoslaviji. Zaśt Bilja 41, 81-93 